\title{
Are the declining trends in forest grouse populations due to changes in the forest age structure? : A case study of Capercaillie in Finland
}

\section{Sirkiä, Saija}

2010

Sirkiä , S , Lindén , A , Helle , P , Nikula , A , Knape , J \& Lindén , H 2010 , ' Are the declining trends in forest grouse populations due to changes in the forest age structure? A case study of Capercaillie in Finland ' , Biological Conservation, vol. 143 , no. 6 , pp. 1540-1548 . https://doi.org/10.1016/j.biocon.2010.03.038

http://hdl.handle.net/10138/23697

https://doi.org/10.1016/j.biocon.2010.03.038

acceptedVersion

Downloaded from Helda, University of Helsinki institutional repository.

This is an electronic reprint of the original article.

This reprint may differ from the original in pagination and typographic detail.

Please cite the original version. 


\title{
Are the declining trends in forest grouse populations due to changes in the forest age structure? A case study of Capercaillie in Finland
}

\author{
Saija Sirkiä ${ }^{\mathrm{a}, \mathrm{b}, *}$, Andreas Lindén $^{\mathrm{a}}$, Pekka Helle ${ }^{\mathrm{c}}$, Ari Nikula ${ }^{\mathrm{d}}$, Jonas Knape ${ }^{\mathrm{e}}$, Harto Lindén ${ }^{\mathrm{b}}$ \\ ${ }^{a}$ Department of Biosciences, University of Helsinki, P.O. Box 65, FI-00014 Helsinki, Finland \\ ${ }^{\mathrm{b}}$ Finnish Game and Fisheries Research Institute, P.O. Box 2, FI-00791 Helsinki, Finland \\ ${ }^{\mathrm{c}}$ Finnish Game and Fisheries Research Institute, Tutkijantie 2 E, FI-90570 Oulu, Finland \\ ${ }^{\mathrm{d}}$ Finnish Forest Research Institute, P.O. Box 16, FI-96301 Rovaniemi, Finland \\ ${ }^{\mathrm{e}}$ Department of Environmental Science, Policy E Management, 137 Mulford Hall \#3114, University of California, Berkeley, CA 94720, USA
}

\section{A R T I C L E I N F O}

\section{Article history:}

Received 17 December 2009

Received in revised form 23 March 2010

Accepted 31 March 2010

Available online 22 April 2010

\section{Keywords:}

Forestry

Grouse

Spatial population dynamics

Tetrao urogallus

Time series analysis

\begin{abstract}
A B S T R A C T
In Finland, Capercaillie (Tetrao urogallus) populations have a history of serious decrease starting from the mid-20th century. The decline is temporally in line with the expansion of modern forestry practices that created major changes in the landscape. We used tetraonid route-censuses from 18 forestry board districts and Finnish forest inventories (data on forest stand structure) to analyze the decline in 19651988. We used information theoretical model selection to evaluate a set of log-linear second order autoregressive models, allowing for spatially correlated process errors. The average trend throughout the country corresponded to an annual decline of $4.01 \%$ (mean of local trends) $\pm 0.24 \%$ (SEM), parallel to a half-life of 17 years. The decline was surprisingly uniform throughout the country (SD $=1.01 \%$ ) and most parsimoniously explained by a geographically constant log-linear trend. At the large scale of observation applied here, population trends could not be explained by the proportional increase of younger forest age classes ( $<40$ years old and $<80$ years old, respectively). Our analysis does not support the hypothesis that the decline in Capercaillie numbers is due to changes in the forest age structure, but we cannot exclude the possibility that other factors behind the decline may have interacted with forestry in general. From a conservation point of view, we caution against over-emphasizing the role of forest age especially at large spatial scales, but leaning also on other research, we recommend that more management efforts would go into the preservation of the overall forest cover and the original physiognomy in single forest patches. (c) 2010 Elsevier Ltd. All rights reserved.
\end{abstract}

\section{Introduction}

Human alteration of natural habitats is the largest single cause for biodiversity loss in the world (Millennium Ecosystem Assessment, 2005). Boreal forest being one of the world's most extensive terrestrial ecosystems (e.g. Haila, 1994; Schmiegelow and Mönkkönen, 2002), the increasing pressure for land conversion in the boreal region is an important conservation issue. Forestry is largely acknowledged to be the driving force in the population declines of boreal forest species in Fennoscandia (e.g. Rassi and Väisänen, 1987; Esseen et al., 1997). The most affected are the species adapted to old forest (e.g. Hansson, 1992; Esseen et al., 1997; Mönkkönen, 1999; Brotons et al., 2003); a common example being

\footnotetext{
Abbreviations: NFI, National Forest Inventory; AIC, Akaike information criterion. * Corresponding author at: Department of Biosciences, University of Helsinki, P.O. Box 65, FI-00014 Helsinki, Finland. Tel.: +358 9191 57728; fax: +358 919157694

E-mail addresses: saija.sirkia@helsinki.fi (S. Sirkiä), andreas.linden@helsinki.fi (A. Lindén), pekka.helle@rktl.fi (P. Helle), ari.nikula@metla.fi (A. Nikula),jknape@ berkeley.edu (J. Knape), harto.linden@rktl.fi (H. Lindén).
}

the declining Capercaillie populations (e.g. Rolstad and Wegge, 1989a).

In general, there is a profound consensus about the role of forestry in the decline of Capercaillie in Europe (e.g. Storch, 2000, 2007; Miettinen et al., 2008). According to several studies, the negative effects of forestry are mostly mediated through lekking site destructions (including the surrounding territories of the males, Rolstad and Wegge, 1987a; Lindén and Pasanen, 1987; Helle et al., 1994) and partly also through overall habitat loss and fragmentation of forests (e.g. Storch, 2000; Miettinen et al., 2008). However, there is no clear analytical evidence of forest age being the number one cause in the decline, although traditionally, Capercaillie has been thought to be dependent on older forests (e.g. Valkeajärvi and Ijäs, 1986; Storch, 1993a; Swenson and Angelstam, 1993), and the large-sized males in particular prefer large oldgrowth forest patches for their traditional lekking sites (Rolstad and Wegge, 1987b, 1989b).

Other possible candidates for the decline include factors directly or indirectly associated with forestry or other human land 
use, e.g. disturbance and artificial constructions (Bevanger, 1995; Baines and Summers, 1997; Ludwig et al., 2008), elevated predation pressure (Kurki et al., 1997, 2000), and lowered bilberry cover (e.g. Storch, 1993b; Lakka and Kouki, 2009); plus factors not clearly associated with forestry, e.g. hunting (see, however, Lindén, 1991) and climate change (Moss et al., 2001; see also Ludwig et al., 2006). Most likely, different factors play different roles depending on the region, and it is highly probable that several simultaneously operating factors act in concert (e.g. Saniga, 2003; Storch, 2000).

Although forests in Finland were quite effectively used for tar production, slash-and-burn cultivation and firewood collection already since the middle of the 18 th century (Tasanen, 2006), large forest areas remained outside intensive use. The first large-scale changes that affected virtually all Finnish forests took place after the Second World War. Selective cuttings were replaced with clear-cuts and artificial regeneration, and cuttings were expanded to previously unmanaged areas (e.g. Leikola, 2006). As a consequence, between the third (1951-1953) and the fourth (19601963) National Forest Inventory (NFI) in Finland, particularly the amounts of saplings (age $<20$ years) and young forests (2140 years) increased remarkably (Tiihonen, 1968). This is temporally in line with the sharp decline in the Finnish Capercaillie populations (Fig. 1; Lindén and Rajala, 1981).

Finnish grouse populations dynamics have been intensively studied, mostly concentrating on their nation-wide cyclic patterns (e.g. Lindström et al., 1995, 1996, 1997; Ranta et al., 1995). Differences in productivity between old and young females, and delayed density dependence in fecundity have been found to be important factors behind the cycles (e.g. Lindström et al., 1997). However, regarding long-term population trends, there have been differing viewpoints on the relative importance between adult survival and breeding success (e.g. Kauhala and Helle, 2002; Ludwig, 2007). Moreover, exact mechanisms behind the declining trends are still mostly unknown, although they are usually considered to be connected with changes in habitats (e.g. Lindén and Rajala, 1981; Helle and Helle, 1991), indicating lowered carrying capacity of the environment (i.e. the population size that the resources of the environment can maintain is lowered, sensu Begon et al., 1996).

In this study, we modelled the spatiotemporal pattern of decline in Finnish Capercaillie populations during 1965-1988. More specifically, we investigated whether changes in the forest age structure, stemming from the expansion of modern forestry practices, could explain population decline. We used information theoretical model selection on several log-linear second order vector autoregressive models to evaluate the effect of forest age structure on the declining Capercaillie density. We hypothesize that the increase of younger forest classes (and consequently, decrease of older forest classes) negatively affects the Capercaillie habitat quality, especially at the lekking sites. This is because the lekking sites surrounded with large areas of old-growth forest support more resident males (Wegge and Rolstad, 1986) probably attracting also more females (Storch, 1997; Gjerde et al., 2000), and the number of displaying males is positively correlated with the lekking site
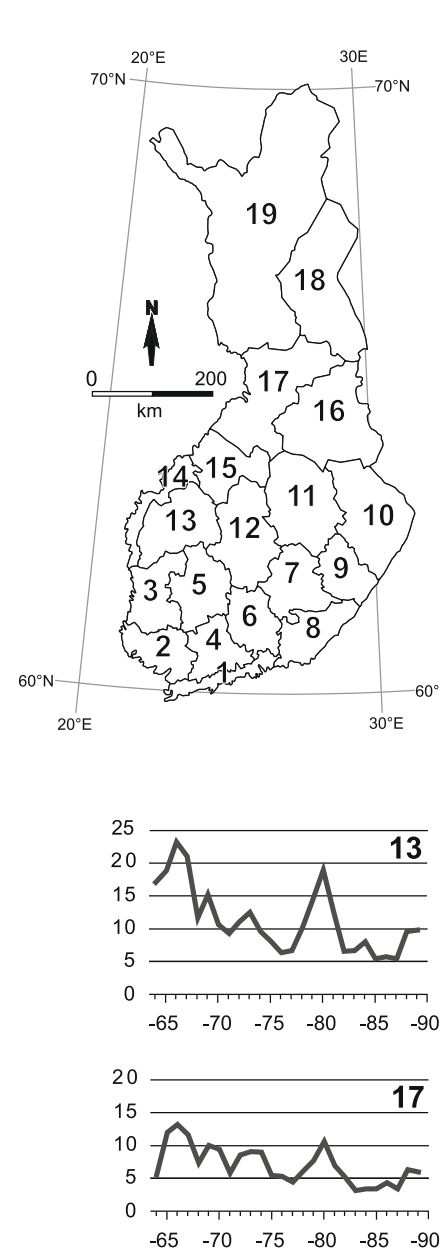
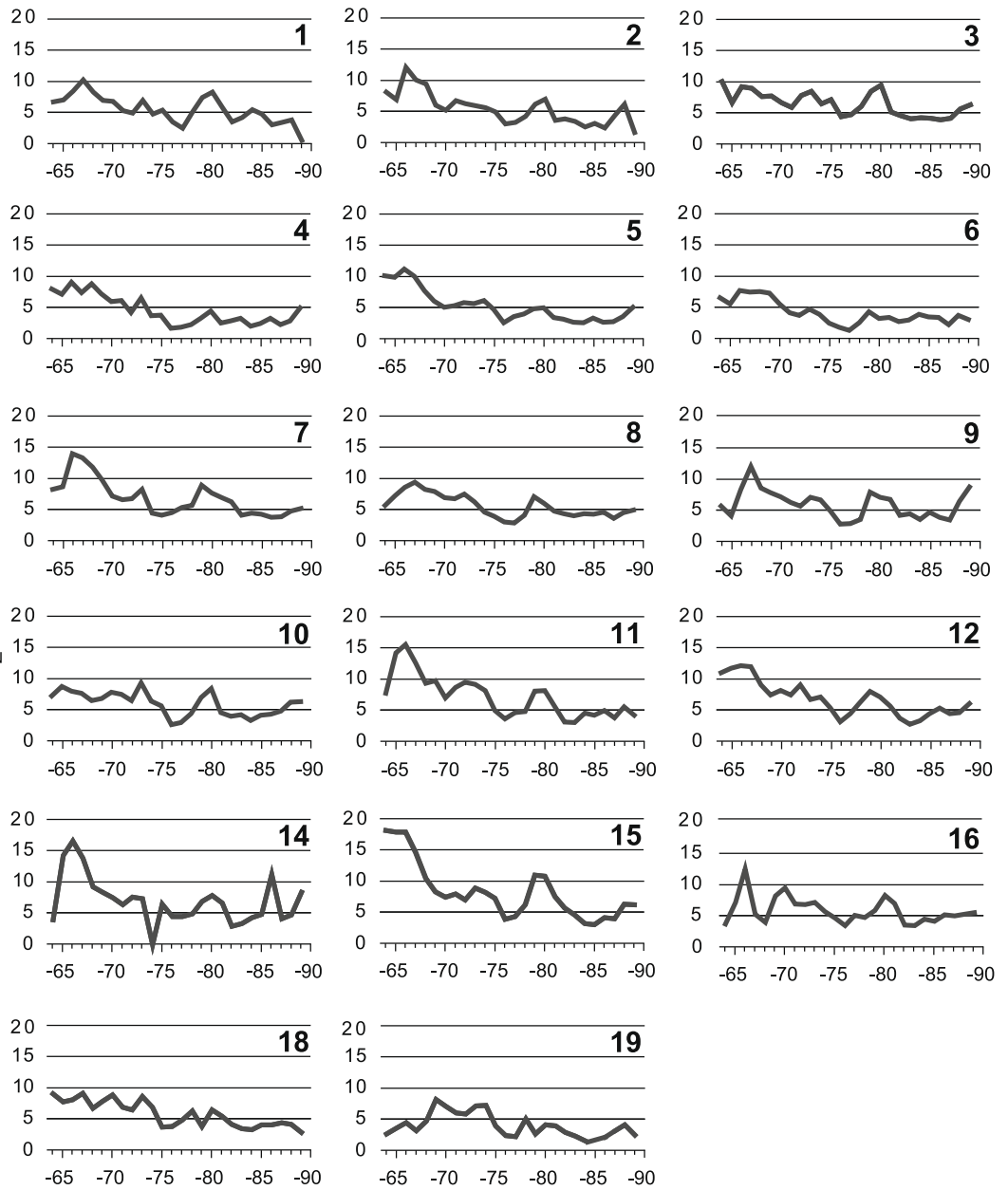

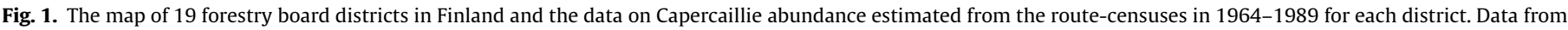
the district number 14 was omitted from the models due to several weak years of data gathering. The data used in the analyses covered years $1965-1988$. 
persistence (Rolstad and Wegge, 1989b). Hence, the immediate effect of forestry actions is likely to be that juveniles and females disperse away from low-quality leks (Rolstad and Wegge, 1989b), which at a large scale connote only spatial restructuring of individuals. Population dynamical effects may therefore occur with a delay, when males at lower quality leks die. Hence, we expect largescale population dynamics to be expressed at the scale of lekking populations, best visible with a time-lag corresponding to the death of the majority of the males. Our aim was to improve the understanding of mechanisms behind the decline, which we think is needed for effective and realistic Capercaillie conservation in Europe, and which may be helpful in conserving forest wildlife biodiversity in general (Pakkala et al., 2003).

\section{Materials and methods}

\subsection{Capercaillie data}

Capercaillie abundance estimates (individuals per $\mathrm{km}^{2}$; see Rajala, 1974) were based on tetraonid route-censuses performed in 1964-1989 (Lindén and Rajala, 1981), but the first and the last year were dropped from the analyses due to low coverage of data. Census routes were located on the very best grouse habitats, such as edges of forests, and the census data comprised relative densities of young and adult birds, estimates of the percentage of hens with a brood and estimates of brood sizes. The routes were counted annually in August by thousands of volunteer hunters. During the study period about 500-800 routes were annually counted, the total route length varying between 20,000 and 30,000 km/year (Lindén and Rajala, 1981). Counts were performed in 19 regions of which 18 were subject to the current analysis (number 14 was excluded due to scarce census data in several years). These areas roughly correspond to the forestry board districts (Fig. 1) which were selected as a spatial unit of the analyses. During the study period, there were some small changes in the administrative borders of the forestry boards, and in these cases Capercaillie density estimates were always corrected to correspond to the limits of forestry board districts.

\subsection{Forest data}

Data on forest cover and age structure were derived from the NFI reports for 18 forestry board districts (Fig. 1 from which number 14 excluded; Ilvessalo, 1957; Kuusela, 1967; Kuusela and Salovaara, 1968, 1969, 1971, 1974a,b; Kuusela and Salminen, 1976, 1978, 1980, 1983; Kuusela et al., 1986; Tomppo et al., 1998). We separated out data on total area of the district $\left(\mathrm{km}^{2}\right)$, total amount of forest land $\left(\mathrm{km}^{2}\right.$ of forest with an average growth of $\geqslant 1 \mathrm{~m}^{3} / \mathrm{ha}$ / year) and forest age classes (the proportion of forests of 1140 years, classified with 20 years intervals, plus all the forests over 140 years [up to 210 years] grouped in their own class, calculated as percentages from the forest land). We used the geographic center ( $N$ - and $E$-coordinates from the Uniform Coordinate System, Grid27E) of every district to describe their locations.

We used data from five inventories which were carried out in 1951-1953 (NFI 3), 1964-1970 (NFI 5), 1971-1976 (NFI 6), 19771982 (NFI 7) and 1986-1994 (NFI 8), once in every district per inventory. Annual values for forest age structure variables (19601981 , i.e. 7 years before the response, see below) were obtained through linear interpolation. Interpolation is justified due to the low temporal resolution of the involved variables: (1) the changes in forest age structure are slow and (2) our aim was to analyze long-term trends in Capercaillie abundances. Because in some forestry board districts the inventories took more than a year, we al- ways used the first year of an inventory as the main data point from which the interpolation was carried out.

The first inventory used (NFI 3; Ilvessalo, 1957) was chosen as a reference point describing the forest age structure in Finland before the modern forestry expansion. As the amount of forest land was defined differently in 1951-1953 the first inventory is not fully comparable to the following ones. However, because the older definition, "fertile forest land" that was used in NFI 3 comprised about $80 \%$ of the "total forest land" that was used in later inventories (Tiihonen, 1966), the difference between the forest variables of separate inventories is probably minor.

\subsection{Choice of the extrinsic variables}

To investigate the effects of forest age structure on Finnish Capercaillie population trends, we used the proportion of forests less than 40 and 80 years of age (percentages from the forest land with an average growth of $\geqslant 1 \mathrm{~m}^{3} /$ ha/year) as explanatory variables, interpolated from the NFIs. The average annual survival of Finnish Capercaillie adults has been estimated to be 0.71 (Lindén, 1981a; see also Moss et al., 2000). Because the expected time until $90 \%$ of the remaining males have died is $\log _{0.71}(1-0.90) \approx 6.72$, we used a lag of 7 years in the forest age variables. We hereafter refer to the site and time specific forest age variables as $A 40_{t-7, i}$ and $A 80_{t-7, i}$.

As an alternative to the forest variables the decline was modelled as an undistinguished exponential declining trend, using year of investigation as an explanatory variable. The variable, hereafter denoted $Y_{t}$, was scaled such that the first year of the response (1967 for the dependent variable) was set to zero. The average Pearson's product moment correlation between $Y$ and A40 is $r=0.89$, so keeping both in the same model simultaneously would cause collinearity problems. Instead, we considered them as competing explanations in the model selection setting.

The coordinates ( $N$ and $E$, Grid27E) of the geographic center in each forestry board district were centered to zero at the average of all forestry boards (N 6974594, E 3435680) and scaled such that one unit corresponds to $100 \mathrm{~km}$. Spatial trends were described with three variables, including site specific scaled $N$-coordinate $\left(N_{i}\right), E$-coordinate $\left(E_{i}\right)$ and the interaction between those two $\left(N_{i} * E_{i}\right)$. Later we refer to these three geographical variables as $\mathrm{GEO}_{i}$. In addition to geographical trends in population densities, geographical gradients in the effects of other explanatory variables were modelled as interactions between those variables and $\mathrm{GEO}_{i}$.

Models with different combinations of the explanatory variables and error structures were compared with an information theoretical approach, according to the Akaike information criterion (AIC) and Akaike weights $(\omega)$. For multivariate models with more specific error structures, as used here, there exist no well established exact versions of $\mathrm{AIC}_{c}$ (Burnham and Anderson, 2002), that is, the AIC corrected for small sample size. Therefore, we used the regular AIC. In total, 14 different competing models were considered in the analysis (Table 1 ).

\subsection{The population models}

The population dynamics were modelled on a logarithmic scale with second order vector autoregressive models of the general form

$X_{t, i}=a_{0}+a_{1} X_{t-1, i}+a_{2} X_{t-2, i}+f\left(\mathrm{~A} 40_{t-7, i}, \mathrm{~A} 80_{t-7, i}, Y_{t}, \mathrm{GEO}_{i}\right)+\varepsilon_{t, i}$

$\varepsilon_{t} \sim N_{18}(0, \Sigma)$

where $X_{t, i}$ is the natural logarithm of population density (young and adult birds together) at time $t$ and location $i$. The expression $f\left(\mathrm{~A} 40_{t-7, i}, \mathrm{~A} 80_{t-7, i}, Y_{t}, \mathrm{GEO}_{i}\right)$ denotes a linear combination of the 
Table 1

The 14 competing models and statistics indicating their degree of support. $R^{2}$ are the coefficients of determination, $K$ are the number of estimated parameters, $\Delta$ AIC are the differences in Akaike information criterion (dev. $+2 \mathrm{~K}$ ) compared to the best model (of which AIC $=-115.72$ ) and $\omega$ are the Akaike weights.

\begin{tabular}{rlllllrl}
\hline Model & Variables & Res. corr. & $R^{2}$ & \multicolumn{1}{l}{$K$} & \multicolumn{1}{l}{ dev. } & \multicolumn{1}{c}{$\Delta$ AIC } & \multicolumn{1}{l}{$\omega$} \\
\hline 9 & $Y$ & Yes & 0.547 & 24 & -163.72 & 0.00 & 0.821 \\
10 & $Y, Y *$ GEO & Yes & 0.548 & 27 & -166.22 & 3.51 & 0.142 \\
8 & - & Yes & 0.429 & 23 & -154.08 & 7.64 & 0.018 \\
13 & A80 & Yes & 0.425 & 24 & -154.25 & 9.48 & 0.007 \\
11 & A40 & Yes & 0.414 & 24 & -154.24 & 9.49 & 0.007 \\
14 & A80, A80 $*$ GEO & Yes & 0.443 & 27 & -158.75 & 10.98 & 0.003 \\
12 & A40, A40 $*$ GEO & Yes & 0.415 & 27 & -157.13 & 12.59 & 0.002 \\
2 & $Y$ & No & 0.593 & 22 & 13.90 & 173.62 & 0.000 \\
3 & $Y, Y *$ GEO & No & 0.594 & 25 & 12.13 & 177.85 & 0.000 \\
4 & A40 & No & 0.568 & 22 & 37.12 & 196.84 & 0.000 \\
5 & A40, A40 $*$ GEO & No & 0.571 & 25 & 34.68 & 200.40 & 0.000 \\
7 & A80, A80 * GEO & No & 0.553 & 25 & 50.94 & 216.66 & 0.000 \\
1 & - & No & 0.538 & 21 & 63.69 & 221.41 & 0.000 \\
6 & A80 & No & 0.539 & 22 & 62.62 & 222.34 & 0.000 \\
\hline
\end{tabular}

variables involved, and interactions between them. This is the part that varies among the competing models given in Table 1. For all models we assume all regression coefficients except the intercept terms $a_{0 i}$ to be identical across all regions. The process errors $\left(\varepsilon_{t}\right)$ are assumed to be multivariate normal with 18 dimensions (locations), zero mean and variance-covariance matrix $(\Sigma)$. We take two competing approaches to spatial synchrony in the process errors: (1) no correlation and (2) the process errors are assumed to be a $50-50 \%$ mixture of spatially correlated noise that decrease in correlation by distance, and compound symmetric noise (correlation between all sites equal). In the potentially correlated version, the elements of $\Sigma$ are a function of the common residual variance $\left(\sigma^{2}\right)$, the distance between the sites $(D(i, j))$, the spatial correlation per unit distance $\left(\rho_{1}\right)$ and the common correlation $\left(\rho_{2}\right)$ :

$\Sigma_{i, j}=0.5 \sigma^{2}\left(\rho_{1}^{D(i, j)}+\rho_{2}\right)$

Our models include only process error, but it is likely that the population indices contain measurement error as well, which could lead to biased estimates of density dependence (Freckleton et al., 2006; Knape, 2008). However, our focus being on large-scale trends in the dynamics, exact estimates of density dependence fall outside the scope of this paper.

The models were fitted using maximum likelihood estimation. The likelihood was maximised using a variant of an iteratively reweighted least squares algorithm. In each iteration regression coefficients were updated by analytically solving for the values that maximised the likelihood while holding the covariance matrix fixed to parameter values obtained from the previous iteration. Each of the parameters to be estimated in the covariance matrix (for Models 1-7: $\sigma^{2}$; for Models 8-14: $\sigma^{2}, \rho_{1}$ and $\rho_{2}$ ) were then updated in turn by holding the remaining parameters fixed to their current values and numerically finding the parameter value that maximised the likelihood (using golden section search implemented in the MATLAB function fminbnd).

Standard errors of the parameters were calculated using parametric bootstrap (data resampled by simulating the fitted model) with 500 bootstrap samples.

\section{Results}

The decline in the Finnish Capercaillie population in 1965-1988 was steep throughout the country. The average trend (i.e. mean of the trends calculated for the 18 districts) corresponds to an annual decline of $4.01 \pm 0.24 \%$ (SEM), parallel to a half-life of about 17 years. The variation in the annual decline between forestry boards is relatively low ( $\mathrm{SD}=1.01 \%$ ). Between 1965 and 1972, a slight increase in Capercaillie density could only be found in the northernmost parts of Finland, and while moving towards 1980s the populations declined again (Fig. 2, uppermost row of panels). In contrast, the proportion of forest less than 40 years old consistently increased most in the east (Fig. 2, middle row of panels). Considering the amount of forest less than 80 years, there were no major temporal changes, merely the differences between northern and southern parts of Finland slightly evened out during the study period (Fig. 2, bottom row of panels).

Among the 14 competing models presented in Table 1, Model 9 was selected by AIC to be the best approximating model (Burnham and Anderson, 2002). Model 9 included a temporal decline $\left(Y_{t}\right)$ only, whereas the second best model (Model 10) included also a geographical gradient in the decline. Both models had synchronous (spatially correlated) process errors. The evidence ratio (ratio of Akaike weights) of Model 9 compared to Model 10 was over 5.77 , indicating a moderately strong support for Model 9 . For other models the evidence ratio of Model 9 was greater than 45, the support being strong. Models 9 and 10 both performed fairly well, explaining over half of the variation in the data (Table 1 ).

The coefficient of temporal decline in the carrying capacity (effect of $Y_{t}$ ) in Model 9 was $-0.023 \pm 0.007$ (SE), corresponding to an annual decline of $2.26 \%$ in the populations' carrying capacities. The average trend in the carrying capacity in Model 10 was similar. An interpretation of the fact that this is less than the observed trend ( $4.01 \%$ ) could be that the population density was far above the carrying capacity in the beginning of the study period.

Models with spatially correlated process errors (Models 8-14) performed altogether better compared to models with independent process errors (Models 1-7, see Table 1 ). Hence, our approach to account for synchrony that decreases by distance was well justified. The synchrony can be caused by dispersal as well as spatially autocorrelated environment (e.g. weather patterns) and is typical for spatiotemporal population data (Ranta et al., 1999) and maybe for large-scale Capercaillie occurrence in general (Mörtberg and Karlström, 2005).

Unexpectedly, the models including forest age performed clearly worse than the models with year as an explanatory variable. In the fourth best model (Model 13, see Table 1) the proportion of forest less than 80 years old (A80) was included, but having an effect close to zero (Appendix A). Hence, at the large scale of investigation used here, it seems that forest age per se does not provide a good explanation for the decline in the Capercaillie populations. It is notable that in the models with A80 and A40, part of the variation in the population trend was picked up by the spatial correlation structure of the process errors $\left(\rho_{1}\right)$. Comparing Models 11 and 4, for example, A40 has a clear negative effect in the model with no spatial correlation among the process errors, but the effect is lost in Model 11 (see Appendix A). For Model 11, we found a negative trend in residuals of the 18 forestry board districts (average trend $-0.022 \pm 0.001$ [SEM], SD=0.005). While no such trend could be found in the residuals of Model 4 or Model 9, it is obvious that A40 cannot fully account for the trend appearing in the dependent variable. The same phenomenon could be seen when comparing Models 5 and 12 (A40 and GEO as explanatory variables, Appendix A). It is possible, that an unknown factor also containing a trend (e.g. climate) not included in our model might have caused synchrony in the process errors.

Although not the focus of the study, density dependent effects $\left(a_{1}\right.$ and $a_{2}$ ) had an important role in the models (Appendix A). In all the models, there were clear first order negative density dependence corresponding to undercompensatory dynamics $\left(0<a_{1}<1\right.$; whereas $a_{1}=1$ correspond to exponential growth). Interestingly, in the models with spatial correlation structure in the process errors, the two-year delayed effect $\left(a_{2}\right)$ disappeared, whereas in the models with independent process errors it was always present 
1965
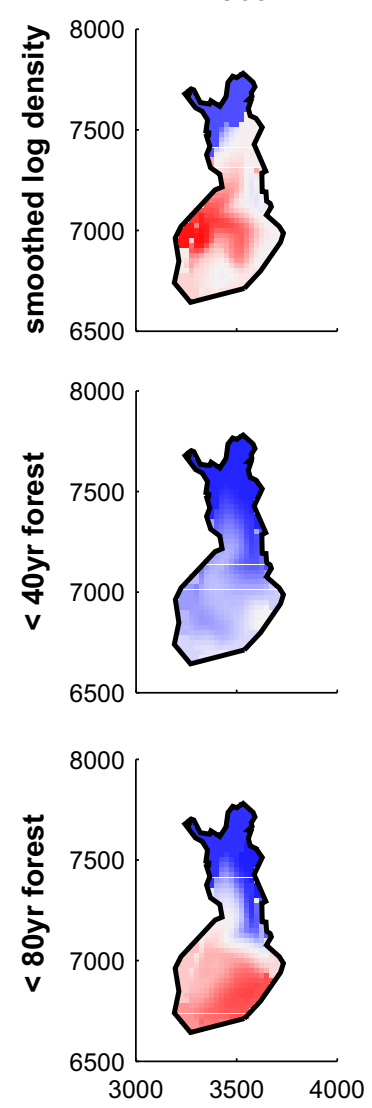

1972
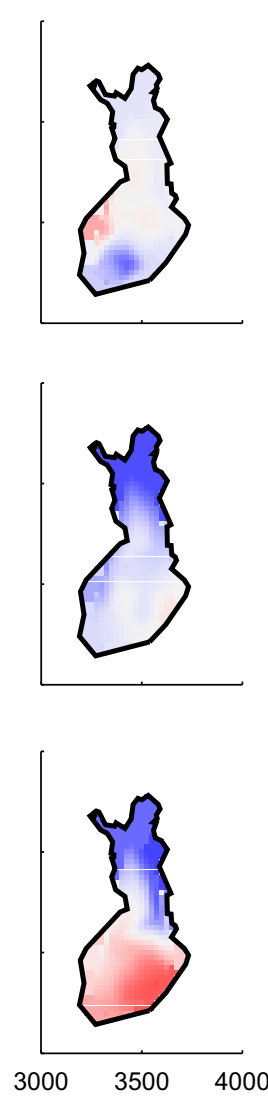

1979
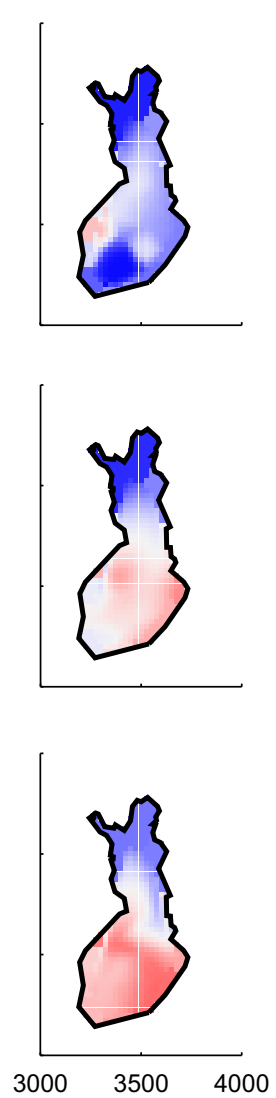

1986
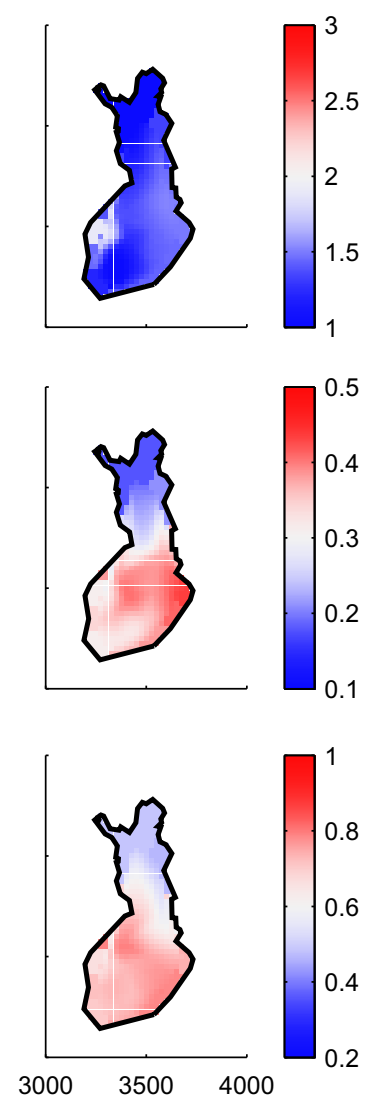

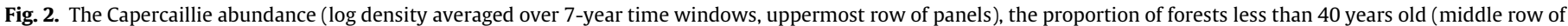

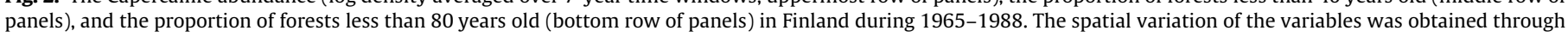
cubic interpolation from the 18 districts. Large values are shown in red, intermediate in light grey and small in blue color.

with a negative effect (Appendix A). Hence, our models suggest that the observed delayed density dependence might actually be a consequence of environmental stochasticity (Jonzén et al., 2002). We caution, however, that since we have not accounted for observation error, our density dependence estimates may be imprecise and biased.

\section{Discussion}

\subsection{Effect of the forest age structure}

Our results revealed that despite the widespread consensus on forestry being among the most important causes for declines in the Capercaillie populations around Europe (e.g. Lindén and Pasanen, 1987; Rolstad and Wegge, 1987a, 1989a; Gjerde and Wegge, 1989; Virkkala, 1991; Helle et al., 1994; Sjöberg, 1996; Storch, 2000, 2007; Saniga, 2003; Sachot et al., 2006), the increase in the proportion of young (less than 40 and 80 years old) forest classes does not provide a good explanation for the decline in Finnish Capercaillie populations. This is somewhat surprising, because lekking sites have traditionally been found in forests older than 6070 years (Valkeajärvi and Ijäs, 1986; Rolstad and Wegge, 1987b), and in some studies suitable Capercaillie habitat has been suggested to be forests older than 90 years (Storch, 1993a; Swenson and Angelstam, 1993). However, according to some more recent papers it seems that Capercaillie might not be a strict old-forest specialist - new lekking sites have been found in young (2646 years, $50-140 \mathrm{~m}^{3} / \mathrm{ha}$ ) forests (Rolstad et al., 2007), and thinning stands (36-100 $\mathrm{m}^{3} / \mathrm{ha}$ ) and other younger forests might be of rea- sonable quality for Capercaillie males (Miettinen et al., 2005, 2008).

Fragmentation of mature forests might have led to situation where some species traditionally connected to older forest classes (e.g. Capercaillie, Swenson and Angelstam, 1993; Angelstam, 2004) nowadays seemingly avoid them, most likely because the extent of a species' home range and the extent of the mature forest area do not match (Mykrä et al., 2000; Miettinen et al., 2005, 2008; Miettinen, 2009). However, this seems to be fairly recent phenomenon: for instance in the Northern Finland, the preference of mature stands for Capercaillie lekking sites was still clearly visible in 1985 (Helle et al., 1989).

It is possible that some other structural aspects of forestry (e.g. impoverishment of habitat's physiognomy, decreased mosaic-like variability, patch size and/or connectivity) are more important than the decline in forest age (Helle et al., 1987; Lindén et al., 2000; Quevedo et al., 2006). It has been suggested, for example, that in the Northern Finland the understorey cover in mature forests may have become too scarce and monotonous for Capercaillie (Miettinen, 2009). In contrast, in some very dense forest stands thinning may create space for large-sized Capercaillie males for winter roosting (Thiel et al., 2007) or for lekking site displaying (Rolstad and Wegge, 1989a; Rolstad et al., 2007). Hence, forest age at large spatial scales might not be the most important aspect for Capercaillie, but some old forest characteristics or structural aspects resembling old forest might still be needed at the stand level (Helle et al., 1989). To conclude, forest age might be more important on smaller spatial scales than the one studied here (e.g. Storch, 1993a; Graf et al., 2005 see also Wallgren et al., 2009). 
Interestingly, it seems that there might have been a decline also in the Swedish Capercaillie populations from the mid-1940s to late 1970s (Marcström, 1979). One cannot exclude the possibility that some common factors have affected the Capercaillie population trends in both countries, which have also many similarities in their past land use (e.g. Esseen et al., 1997). However, the Swedish populations have since been more or less stable, at least according to trend analysis from 1975 to 2007 (results concerning mostly southern Sweden, The Swedish Bird Survey, 2010). In Finland, the declining Capercaillie population trend started to partly stabilize from 1990s onwards, although large variation still exists depending on the game management district (Lindén, 2002).

\subsection{Other factors associated with forestry}

Our results further implied that the Capercaillie population density might have been far above the carrying capacity in the beginning of the study period. According to some indirect evidence, Capercaillie populations might have been on the highest level recorded so far in the end of 1930s (Airaksinen, 1946; Mäki, 1946), and in 1953 the populations were apparently still about 40\% higher than in the 'high-density-years' 1966-1967 (when the relative density was over 10 birds $/ \mathrm{km}^{2}$, Lindén and Rajala, 1981; Lindén, 2002). We cannot rule out the possibility that some other factors associated with forestry, but not included in our model, might have affected the carrying capacity already before our study period (see also Löfman and Kouki, 2001). For example, logging may reduce the amount of suitable food and cover for juveniles and disturb dispersal (e.g. Hannon and Martin, 2006), and large-scale forest drainage can have both direct and indirect negative effects on grouse productivity (Ludwig et al., 2008). More specifically, there are two forestry-related factors that have often been suggested to be potential mechanisms behind grouse population declines: (1) increased predation pressure and (2) decreased food quality/quantity (e.g. Kurki et al., 2000; Storch, 2000, 2007; Lakka and Kouki, 2009).

Predation is a major proximate cause for grouse chick and juvenile mortality (Hannon and Martin, 2006; Baines et al., 2007), and it may also affect adult survival especially in low-density populations (Park et al., 2008). Concerning our results, interactions between enhanced predation pressure and changes in the landscape-level habitat quantity and quality (Henttonen, 1989; Kurki et al., 1997, 2000; Storaas et al., 1999) may have at least partly played a role in the temporally uniform decline of Capercaillie populations (and possibly also other grouse species in Finland; Kurki et al., 2000). However, predation does not well explain the spatial synchrony of our results. The densities of the most common predators (e.g. red fox) might be two- to threefold higher in the southernmost Finland, and the negative effect on grouse breeding success therefore usually varies between south and north (Kurki et al., 1997, 2000).

Bilberry (Vaccinium myrtillus) cover is an important variable explaining Capercaillie abundance (Storch, 1993a,b), and is commonly associated with the abundance of insect food important for chicks (Wegge et al., 2005; Lakka and Kouki, 2009). The longterm decrease in the Finnish bilberry cover (Reinikainen et al., 2000) may be among the proximate causes for bad Capercaillie breeding success, ultimate cause being habitat alteration (Ludwig, 2007; see also Ludwig et al., 2008; Lakka and Kouki, 2009). This kind of explanation might match the pattern of a spatially and temporally uniform decline, although Lakka and Kouki (2009) concluded that it is unlikely that bilberry abundance alone can explain the decline in Finnish Capercaillie populations. However, it is well known that clear-cutting negatively affects bilberry cover (Atlegrim and Sjöberg, 1996a) and the herbivorous insect larvae feeding on it (Atlegrim and Sjöberg, 1996b). Ordinary forest management practices may thus at least momentarily lower Capercaillie breeding success through bilberry reduction (Baines et al., 2004).

\subsection{Factors not associated with forestry}

Local weather patterns can affect grouse population dynamics, especially through breeding success (e.g. Virkkala, 1991; Sæther et al., 2004; Baines et al., 2007). Moreover, asymmetrical climate change has been connected to long-term grouse declines in earlier studies (Moss et al., 2001; Ludwig et al., 2006). Climate change could be a candidate to explain the spatially uniform decline found in our study, but the temporal match is poor. Moreover, from the beginning of 1990s Finnish Capercaillie population estimates have shown signs of stabilization or even increment in some parts of the country, indicating improved breeding success (Lindén, 2002), whereas the climate has continued to warm up (Karl and Trenberth, 2003). In sum, the role of climate change in Capercaillie population decline remains unclear.

The effects of hunting on Capercaillie populations have been rather little studied (Baines and Lindén, 1991; Kangas and Kurki, 2000). In 1964-1972, bag sizes followed the cyclic abundances, although more encouraging population trends were observed in the protected areas compared to the hunted ones (Lindén, 1981b). For the period of 1973-1984 Lindén (1991) did not find significant correlative relationships between grouse population trends and the annual bag, albeit there may have been some overharvesting in the Northern Finland. Because of the remarkable spatial synchrony detected in the population trend, it is hard to believe that hunting is the most important factor behind the Capercaillie decline in Finland. However, hunting has the potential to cause population declines, especially together with some other factors. For example, the dense network of forest roads not only increases forest fragmentation but creates also opportunities for hunters, which may lead to local overhunting (Lindén, 1991). Selective hunting would be especially harmful if directed towards highquality lekking males because of their high reproductive value, and the potential negative effects on the display and sex ratio (Lindén, 1981b; Ellison, 1991).

\section{Conclusion and management implications}

Our study shows that the causes for Capercaillie population decline are difficult to pinpoint on statistical grounds because of the spatio-temporally uniform decrease in the population density. It is probable that several interacting factors are responsible for the decline (e.g. Ludwig, 2007). For example, effects of climate change may depend on habitat fragmentation (e.g. Foppen et al., 1999). We caution against over-emphasizing the role of forest age structure in the forest management, until the mechanisms behind the decline have been uncovered. However, leaning also on other research we wish that at large spatial scales, more effort would go into the preservation of the overall forest cover, especially around the functioning Capercaillie lekking sites (e.g. Lindén and Pasanen, 1987; Helle et al., 1994; Lindén et al., 2000). In Southern Finland, for example, functioning lekking sites are situated in forest patches that are substantially larger than average (Lindén and Pasanen, 1987; Helle et al., 1994). Since Capercaillie is recognized as an umbrella species, successful conservation efforts would benefit forest biodiversity in general (Pakkala et al., 2003). Moreover, increasing the amount of suitable habitat would offer a precaution to minimize risks e.g. connected to future range shifts stemming from climate change (Thomas and Lennon, 1999). In addition, in single forest patches preservation of the original forest physiognomy might be of importance. Although not explicitly detected in this 
study, large-scale changes in human land use are evident threats to forest biodiversity around the world. Compared to Central European forests which are seriously fragmented primarily due to the patchy distribution of mountainous conifer forests and secondly because of habitat loss, forests in Fennoscandia comprise the last wide-enough habitats for many large forest-dwelling species in Europe (e.g. Storch, 2000; Mikusiński et al., 2007), including Capercaillie (see also Segelbacher and Storch, 2002; Segelbacher et al., 2003), and are therefore of primary concern for species conservation. in the preparation of Fig. 1. This work is dedicated to our dear colleague, mentor and friend, Professor Esa Ranta (1953-2008).

\section{Appendix A}

Parameter estimates and standard errors (in parentheses) for the 14 competing models. Parameters for which $|b|>2$ SE are considered to differ from zero and are bolded, excluding error variances $\left(\sigma^{2}\right)$. The intercepts $\left(a_{0(1)}-a_{0(18)}\right)$ are not shown.

\begin{tabular}{|c|c|c|c|c|c|c|c|c|c|c|c|c|c|c|}
\hline & $\begin{array}{l}\text { Model } \\
1 \\
\end{array}$ & $\begin{array}{l}\text { Model } \\
2 \\
\end{array}$ & $\begin{array}{l}\text { Model } \\
3 \\
\end{array}$ & $\begin{array}{l}\text { Model } \\
4 \\
\end{array}$ & $\begin{array}{l}\text { Model } \\
5 \\
\end{array}$ & $\begin{array}{l}\text { Model } \\
6 \\
\end{array}$ & $\begin{array}{l}\text { Model } \\
7 \\
\end{array}$ & $\begin{array}{l}\text { Model } \\
8 \\
\end{array}$ & $\begin{array}{l}\text { Model } \\
9 \\
\end{array}$ & $\begin{array}{l}\text { Model } \\
10 \\
\end{array}$ & $\begin{array}{l}\text { Model } \\
11 \\
\end{array}$ & $\begin{array}{l}\text { Model } \\
12 \\
\end{array}$ & $\begin{array}{l}\text { Model } \\
13 \\
\end{array}$ & $\begin{array}{l}\text { Model } \\
14 \\
\end{array}$ \\
\hline$a_{1}-1$ & $\begin{array}{l}-\mathbf{0 . 2 0 7} \\
(0.048)\end{array}$ & $\begin{array}{l}-\mathbf{0 . 3 4 6} \\
(0.051)\end{array}$ & $\begin{array}{l}-\mathbf{0 . 3 4 9} \\
(0.048)\end{array}$ & $\begin{array}{l}-\mathbf{0 . 2 7 7} \\
(0.048)\end{array}$ & $\begin{array}{l}-\mathbf{0 . 2 8 3} \\
(0.049)\end{array}$ & $\begin{array}{l}-\mathbf{0 . 2 0 8} \\
(0.048)\end{array}$ & $\begin{array}{l}-\mathbf{0 . 2 4 3} \\
(0.048)\end{array}$ & $\begin{array}{l}-\mathbf{0 . 6 1 9} \\
(0.051)\end{array}$ & $\begin{array}{c}-\mathbf{0 . 6 3 6} \\
(0.050)\end{array}$ & $\begin{array}{c}-\mathbf{0 . 6 4 3} \\
(0.050)\end{array}$ & $\begin{array}{l}-\mathbf{0 . 6 2 1} \\
(0.053)\end{array}$ & $\begin{array}{l}-\mathbf{0 . 6 3 1} \\
(0.047)\end{array}$ & $\begin{array}{l}-\mathbf{0 . 6 2 2} \\
(0.049)\end{array}$ & $\begin{array}{r}-\mathbf{0 . 6 2 9} \\
(0.055)\end{array}$ \\
\hline$a_{2}$ & $\begin{array}{l}-\mathbf{0 . 1 5 7} \\
(0.047)\end{array}$ & $\begin{array}{l}-\mathbf{0 . 2 8 8} \\
(0.051)\end{array}$ & $\begin{array}{l}-0.292 \\
(0.048)\end{array}$ & $\begin{array}{l}-\mathbf{0 . 2 3 5} \\
(0.050)\end{array}$ & $\begin{array}{r}-\mathbf{0 . 2 4 0} \\
(0.049)\end{array}$ & $\begin{array}{r}-\mathbf{0 . 1 6 0} \\
(0.049)\end{array}$ & $\begin{array}{l}-\mathbf{0 . 1 8 2} \\
(0.049)\end{array}$ & $\begin{array}{l}0.011 \\
(0.051)\end{array}$ & $\begin{array}{l}-0.021 \\
(0.050)\end{array}$ & $\begin{array}{l}-0.027 \\
(0.049)\end{array}$ & $\begin{array}{l}0.011 \\
(0.051)\end{array}$ & $\begin{array}{l}0.006 \\
(0.049)\end{array}$ & $\begin{array}{l}0.010 \\
(0.048)\end{array}$ & $\begin{array}{l}0.006 \\
(0.050)\end{array}$ \\
\hline Y & 0 & $\begin{array}{r}-0.022 \\
(0.003)\end{array}$ & $\begin{array}{l}-\mathbf{0 . 0 2 3} \\
(0.003)\end{array}$ & 0 & 0 & 0 & 0 & 0 & $\begin{array}{r}-\mathbf{0 . 0 2 3} \\
(0.007)\end{array}$ & $\begin{array}{l}-\mathbf{0 . 0 2 4} \\
(0.007)\end{array}$ & 0 & 0 & 0 & 0 \\
\hline$Y * N$ & 0 & 0 & $\begin{array}{l}-0.001 \\
(0.001)\end{array}$ & 0 & 0 & 0 & 0 & 0 & 0 & $\begin{array}{l}-0.001 \\
(0.001)\end{array}$ & 0 & 0 & 0 & 0 \\
\hline$Y * E$ & 0 & 0 & $\begin{array}{l}0.002 \\
(0.002)\end{array}$ & 0 & 0 & 0 & 0 & 0 & 0 & $\begin{array}{l}0.00 \\
(0.002)\end{array}$ & 0 & 0 & 0 & 0 \\
\hline$Y * N * E$ & 0 & 0 & $\begin{array}{l}0.001 \\
(0.001)\end{array}$ & 0 & 0 & 0 & 0 & 0 & 0 & $\begin{array}{l}0.001 \\
(0.001)\end{array}$ & 0 & 0 & 0 & 0 \\
\hline A40 & 0 & 0 & 0 & $\begin{array}{l}-\mathbf{2 . 1 3 5} \\
(0.412)\end{array}$ & $\begin{array}{l}-\mathbf{2 . 2 5 9} \\
(0.443)\end{array}$ & 0 & 0 & 0 & 0 & 0 & $\begin{array}{l}0.207 \\
(0.507)\end{array}$ & $\begin{array}{l}-0.018 \\
(0.527)\end{array}$ & 0 & 0 \\
\hline $\mathrm{A} 40 * N$ & 0 & 0 & 0 & 0 & $\begin{array}{l}0.045 \\
(0.214)\end{array}$ & 0 & 0 & 0 & 0 & 0 & 0 & $\begin{array}{l}0.120 \\
(0.206)\end{array}$ & 0 & 0 \\
\hline $\mathrm{A} 40 * E$ & 0 & 0 & 0 & 0 & $\begin{array}{l}0.340 \\
(0.257)\end{array}$ & 0 & 0 & 0 & 0 & 0 & 0 & $\begin{array}{l}0.271 \\
(0.220)\end{array}$ & 0 & 0 \\
\hline $\mathrm{A} 40 * N * E$ & 0 & 0 & 0 & 0 & $\begin{array}{l}-0.056 \\
(0.221)\end{array}$ & 0 & 0 & 0 & 0 & 0 & 0 & $\begin{array}{l}0.118 \\
(0.170)\end{array}$ & 0 & 0 \\
\hline A80 & 0 & 0 & 0 & 0 & 0 & $\begin{array}{l}-0.407 \\
(0.392)\end{array}$ & $\begin{array}{l}0.473 \\
(0.560)\end{array}$ & 0 & 0 & 0 & 0 & 0 & $\begin{array}{l}0.158 \\
(0.387)\end{array}$ & $\begin{array}{l}0.131 \\
(0.448)\end{array}$ \\
\hline $\mathrm{A} 80 * N$ & 0 & 0 & 0 & 0 & 0 & 0 & $\begin{array}{l}-\mathbf{0 . 5 8 6} \\
(0.179)\end{array}$ & 0 & 0 & 0 & 0 & 0 & 0 & $\begin{array}{l}-0.290 \\
(0.149)\end{array}$ \\
\hline $\mathrm{A} 80 * E$ & 0 & 0 & 0 & 0 & 0 & 0 & $\begin{array}{l}-0.034 \\
(0.452)\end{array}$ & 0 & 0 & 0 & 0 & 0 & 0 & $\begin{array}{l}0.222 \\
(0.310)\end{array}$ \\
\hline $\mathrm{A} 80 * N * E$ & & 0 & 0 & 0 & 0 & 0 & $\begin{array}{l}0.127 \\
(0.201)\end{array}$ & 0 & 0 & 0 & 0 & 0 & 0 & $\begin{array}{l}0.139 \\
(0.140)\end{array}$ \\
\hline$\sigma^{2}$ & $\begin{array}{l}0.069 \\
(0.005)\end{array}$ & $\begin{array}{l}0.061 \\
(0.004)\end{array}$ & $\begin{array}{l}0.060 \\
(0.004)\end{array}$ & $\begin{array}{l}0.064 \\
(0.004)\end{array}$ & $\begin{array}{l}0.064 \\
(0.004)\end{array}$ & $\begin{array}{l}0.069 \\
(0.005)\end{array}$ & $\begin{array}{l}0.067 \\
(0.005)\end{array}$ & $\begin{array}{l}0.088 \\
(0.015)\end{array}$ & $\begin{array}{l}0.070 \\
(0.011)\end{array}$ & $\begin{array}{l}0.069 \\
(0.010)\end{array}$ & $\begin{array}{l}0.090 \\
(0.017)\end{array}$ & $\begin{array}{l}0.091 \\
(0.018)\end{array}$ & $\begin{array}{l}0.089 \\
(0.017)\end{array}$ & $\begin{array}{l}0.084 \\
(0.015)\end{array}$ \\
\hline$\rho_{1}$ & 0 & 0 & 0 & 0 & 0 & 0 & 0 & $\begin{array}{l}\mathbf{0 . 9 0 8} \\
(0.292)\end{array}$ & $\begin{array}{l}\mathbf{0 . 8 8 2} \\
(0.290)\end{array}$ & $\begin{array}{l}\mathbf{0 . 8 8 4} \\
(0.299)\end{array}$ & $\begin{array}{l}\mathbf{0 . 9 1 1} \\
(0.312)\end{array}$ & $\begin{array}{l}\mathbf{0 . 9 1 5} \\
(0.318)\end{array}$ & $\begin{array}{l}\mathbf{0 . 9 0 9} \\
(0.296)\end{array}$ & $\begin{array}{l}\mathbf{0 . 9 0 4} \\
(0.316)\end{array}$ \\
\hline$\rho_{2}$ & 0 & 0 & 0 & 0 & 0 & 0 & 0 & $\begin{array}{l}0.457 \\
(0.243)\end{array}$ & $\begin{array}{l}0.314 \\
(0.284)\end{array}$ & $\begin{array}{l}0.310 \\
(0.294)\end{array}$ & $\begin{array}{l}0.469 \\
(0.239)\end{array}$ & $\begin{array}{l}0.479 \\
(0.239)\end{array}$ & $\begin{array}{l}0.466 \\
(0.237)\end{array}$ & $\begin{array}{l}0.433 \\
(0.251)\end{array}$ \\
\hline
\end{tabular}

\section{Conflicts of interest}

The authors declare that they have no conflicts of interest.

\section{Role of the funding source}

The study had no external sponsors.

\section{Acknowledgments}

We are grateful for all the voluntarily effort put into the Capercaillie census counts. We thank Mr. Raimo Pikkupeura for the help

\section{References}

Airaksinen, K., 1946. Kanalintujen runsaudenvaihtelusta Suomessa. Suomen Riista 1, 75-92 (in Finnish).

Angelstam, P., 2004. Habitat thresholds and effects of forest landscape change on the distribution and abundance of black grouse and capercaillie. Ecol. Bull. 51 173-187.

Atlegrim, O., Sjöberg, K., 1996a. Response of bilberry (Vaccinium myrtillus) to clearcutting and single-tree selection harvests in uneven-aged boreal Picea abies forests. Forest Ecol. Manage. 86, 39-50.

Atlegrim, O., Sjöberg, K. 1996b. Effects of clear-cutting and single-tree selection harvests on herbivorous insect larvae feeding on bilberry (Vaccinium myrtillus) in uneven-aged boreal Picea abies forests. Forest Ecol. Manage. 87, 139-148.

Baines, D., Lindén, H., 1991. Workshop summary: the impact of hunting on grouse population dynamics. Ornis Scand. 22, 245-246.

Baines, D., Summers, R.W., 1997. Assessment of bird collisions with deer fences in Scottish forests. J. Appl. Ecol. 34, 941-948. 
Baines, D., Moss, R., Dugan, D., 2004. Capercaillie breeding success in relation to forest habitat and predator abundance. J. Appl. Ecol. 41, 59-71.

Baines, D., Warren, P., Richardson, M., 2007. Variations in the vital rates of black grouse Tetrao tetrix in the United Kingdom. Wildlife Biol. 13 (Suppl. 1), 109116.

Begon, M., Harper, J.L., Townsend, C.R., 1996. Ecology: Individuals, Populations and Communities, third ed. Blackwell Science Ltd., Oxford.

Bevanger, K., 1995. Estimates and population consequences of tetraonid mortality caused by collisions with high tension power lines in Norway. J. Appl. Ecol. 32, 745-753.

Brotons, L., Mönkkönen, M., Huhta, E., Nikula, A., Rajasärkkä, A., 2003. Effects of landscape structure and forest reserve location on old-growth forest bird species in Northern Finland. Landscape Ecol. 18, 377-393.

Burnham, K.P., Anderson, D.R., 2002. Model Selection and Multimodel Inference. A Practical Information-Theoretic Approach, second ed. Springer-Verlag, New York.

Ellison, L.N., 1991. Shooting and compensatory mortality in tetraonids. Ornis Scand. 22, 229-240.

Esseen, P.-A., Ehnström, B., Ericson, L., Sjöberg, K., 1997. Boreal forests. Ecol. Bull. 46, 16-47.

Foppen, R., ter Braak, C.J.F., Verboom, J., Reijnen, R., 1999. Dutch sedge warblers Acrocephalus schoenobaenus and West-African rainfall: empirical data and simulation modelling show low population resilience in fragmented marshlands. Ardea 87, 113-127.

Freckleton, R.P., Watkinson, A.R., Green, R.E., Sutherland, W.J., 2006. Census error and the detection of density dependence. J. Anim. Ecol. 75, 837-851.

Gjerde, I., Wegge, P., 1989. Spacing pattern, habitat use and survival of Capercaillie in a fragmented winter habitat. Ornis Scand. 20, 219-225.

Gjerde, I., Wegge, P., Rolstad, J., 2000. Lost hotspots and passive female preference. the dynamic process of lek formation in Capercaillie Tetrao urogallus. Wildlife Biol. 6, 291-298.

Graf, R.F., Bollmann, K., Suter, W., Bugmann, H., 2005. The importance of spatial scale in habitat models: Capercaillie in the Swiss Alps. Landscape Ecol. 20, 703-717.

Haila, Y., 1994. Preserving ecological diversity in boreal forests: ecological background, research, and management. Ann. Zool. Fenn. 31, 203-217.

Hannon, S.J., Martin, K., 2006. Ecology of juvenile grouse during the transition to adulthood. J. Zool. 269, 422-433.

Hansson, L., 1992. Landscape ecology of boreal forests. Trends Ecol. Evol. 7, 229302.

Helle, P., Helle, T., 1991. How do changes in forest structure explain recent changes in Finnish grouse populations. Suomen Riista 37, 56-66 (in Finnish with English summary).

Helle, T., Taskinen, E., Lindén, H., Hokka, P., 1987. Tetraonid habitats and forestry. Suomen Riista 34, 77-95 (in Finnish with English summary).

Helle, T., Helle, P., Lindén, H., Kilpelä, S.-S., 1989. Stand characteristics of capercaillie lekking sites in northern Finland. Suomen Riista 35, 26-35 (in Finnish with English summary).

Helle, P., Helle, T., Lindén, H., 1994. Capercaillie (Tetrao urogallus) lekking sites in fragmented Finnish forest landscape. Scand. J. Forest Res. 9, 386-396.

Henttonen, H., 1989. Does an increase in the rodent and predator densities, resulting from modern forestry, contribute to the long-term decline in Finnish tetraonids? Suomen Riista 35, 83-90 (in Finnish with English summary).

Ilvessalo, Y., 1957. The forests of Finland by forestry board districts. Results of the National Forest Inventory. Metsäntutkimuslaitoksen Julkaisuja 47, 1-128 (in Finnish with English summary).

Jonzén, N., Lundberg, P., Ranta, E., Kaitala, V., 2002. The irreducible uncertainty of the demography-environment interaction in ecology. Proc. R. Soc. Lond. B 269, 221-225.

Kangas, A., Kurki, S., 2000. Predicting the future of Capercaillie (Tetrao urogallus) in Finland. Ecol. Model. 134, 73-87.

Karl, T.R., Trenberth, K.E., 2003. Modern global climate change. Science 302, 1719.

Kauhala, K., Helle, P., 2002. The impact of predator abundance on grouse populations in Finland - a study based on wildlife monitoring counts. Ornis Fenn. 79, 14-25.

Knape, J., 2008. Estimability of density dependence in models of time series data. Ecology 89, 2994-3000.

Kurki, S., Helle, P., Lindén, H., Nikula, A., 1997. Breeding success of black grouse and capercaillie in relation to mammalian predator densities on two spatial scales. Oikos 79, 301-310.

Kurki, S., Nikula, A., Helle, P., Lindén, H., 2000. Landscape fragmentation and forest composition effects on grouse breeding success in boreal forests. Ecology 81, 1985-1997.

Kuusela, K., 1967. Forest resources in the Forestry Board Districts of Helsinki, Lounais-Suomi, Satakunta, Uusimaa-Häme, Pohjois-Häme and Itä-Häme in 1964-65. Folia For. 27, 1-56 (in Finnish with English summary).

Kuusela, K., Salminen, S., 1976. Forest resources in the Forestry Board Districts of Pohjois-Karjala in 1973-74, Etelä-Pohjanmaa, Vaasa and Keski-Pohjanmaa in 1974, Kainuu and Pohjois-Pohjanmaa in 1975. Folia For. 274, 1-43 (in Finnish with English summary).

Kuusela, K., Salminen, S., 1978. Forest resources in the Forestry Board Districts of Koillis-Suomi in 1976 and Lappi in 1970 and 1974-76. Folia For. 337, 1-35 (in Finnish with English summary).

Kuusela, K., Salminen, S., 1980. Forest resources in the Province of Ahvenanmaa and the nine southernmost Forestry Board Districts in Finland 1977-79. Folia For. 446, 1-90 (in Finnish with English summary).
Kuusela, K., Salminen, S., 1983. Forest resources in the six northernmost Forestry Board Districts of South Finland, 1979-1982, and in the whole South Finland, 1977-1982. Folia For. 568, 1-79 (in Finnish with English summary).

Kuusela, K., Salovaara, A., 1968. Forest resources in the Forestry Board Districts of Etelä-Savo, Etelä-Karjala, Itä-Savo, Pohjois-Karjala, Pohjois-Savo and Keski-Suomi in 1966-67. Folia For. 42, 1-54 (in Finnish with English summary).

Kuusela, K., Salovaara, A., 1969. Forest resources in the Forestry Board Districts of Etelä-Pohjanmaa, Vaasa and Keski-Pohjanmaa in 1968. Folia For. 62, 1-42 (in Finnish with English summary).

Kuusela, K., Salovaara, A., 1971. Forest resources in the Forestry Board Districts of Kainuu, Pohjois-Pohjanmaa, Koillis-Suomi and Lappi in 1969-70. Folia For. 110, 1-49 (in Finnish with English summary).

Kuusela, K., Salovaara, A., 1974a. Forest resources in the District of Ahvenanmaa, and the Forestry Board District of Helsinki, Lounais-Suomi, Satakunta, UusimaaHäme, Pirkka-Häme, Etelä-Savo and Etelä-Karjala in 1971-72. Folia For. 191, 163 (in Finnish with English summary).

Kuusela, K., Salovaara, A., 1974b. Forest resources in the Forestry Board Districts of Etelä-Karjala, Pohjois-Savo, Keski-Suomi and Itä-Savo in 1973. Folia For. 207, 135 (in Finnish with English summary).

Kuusela, K., Mattila, E., Salminen, S., 1986. Forest resources in North Finland by Forestry Board Districts, 1982 to 1984. Folia For. 655, 1-86 (in Finnish with English summary).

Lakka, J., Kouki, J., 2009. Patterns of field layer invertebrates in successional stages of managed boreal forests: Implications for the declining Capercaillie Tetrao urogallus L. population. Forest Ecol. Manage. 257, 600-607.

Leikola, M., 2006. The development of silviculture and forest management in 20th century Finland. In: Rauhalahti, M. (Ed.), Vuosilusto 2004-2005: Essays on the History of Finnish Forestry. Vammalan Kirjapaino, Vammala, pp. 33-48.

Lindén, H., 1981a. Estimation of juvenile mortality in the capercaillie, Tetrao urogallus, and the black grouse, Tetrao tetrix, from indirect evidence. Finn. Game Res. 39, 35-51.

Lindén, H., 1981b. Hunting and tetraonid populations in Finland. Finn. Game Res. 39, 69-78.

Lindén, H., 1991. Patterns of grouse shooting in Finland. Ornis Scand. 22, 241-244.

Lindén, H. (Ed.), 2002. Metsäkanalintututkimuksia: Metsäkanalintukannat. Gummerus Kirjapaino Oy, Saarijärvi (in Finnish).

Lindén, H., Pasanen, J., 1987. Capercaillie leks are threatened by forest fragmentation. Suomen Riista 34, 66-76 (in Finnish with English summary).

Lindén, H., Rajala, P., 1981. Fluctuations and long-term trends in the relative densities of tetraonid populations in Finland, 1964-77. Finn. Game Res. 39, 1334.

Lindén, H., Danilov, P.I., Gromtsev, A.N., Helle, P., Ivanter, E.V., Kurhinen, J., 2000. Large-scale forest corridors to connect the taiga fauna to Fennoscandia. Wildlife Biol. 6, 179-188.

Lindström, J., Ranta, E., Kaitala, V., Lindén, H., 1995. The clockwork of Finnish tetraonid population dynamics. Oikos 74, 185-194.

Lindström, J., Ranta, E., Lindén, H., 1996. Large-scale synchrony in the dynamics of Capercaillie, Black Grouse and Hazel Grouse populations in Finland. Oikos 76, 221-227.

Lindström, J., Ranta, E., Lindén, M., Lindén, H., 1997. Reproductive output, population structure and cyclic dynamics in Capercaillie, Black Grouse and Hazel Grouse. J. Avian Biol. 28, 1-8.

Löfman, S., Kouki, J., 2001. Fifty years of landscape transformation in managed forests of Southern Finland. Scand. J. Forest Res. 16, 44-53.

Ludwig, G., 2007. Mechanisms of Population Declines in Boreal Forest Grouse. Jyväskylä University Printing House, Jyväskylä.

Ludwig, G.X., Alatalo, R.V., Helle, P., Lindén, H., Lindström, J., Siitari, H., 2006. Shortand long-term population dynamical consequences of asymmetric climate change in black grouse. Proc. R. Soc. Lond. B 273, 2009-2016.

Ludwig, G.X., Alatalo, R.V., Helle, P., Nissinen, K., Siitari, H., 2008. Large-scale drainage and breeding success in boreal forest grouse. J. Appl. Ecol.. doi:10.1111/j.1365-2664.2007.01396.x.

Mäki, T.V., 1946. Metson esiintymisestä Suomessa vv. 1933-42 metsästyskorttitilastojen perusteella sekä metsästyskorttitilastojen merkityksestä. Suomen Riista 1, 31-48 (in Finnish).

Marcström, V., 1979. A review of the tetraonid situation in Sweden. Proc. Int. Grouse Symp. 1, 13-16.

Miettinen, J., 2009. Capercaillie (Tetrao urogallus L.) habitats in managed Finnish forests - the current status, threats and possibilities. Dissertationes Forestales 90. <http://www.metla.fi/dissertationes/df90.htm>.

Miettinen, J., Helle, P., Nikula, A., 2005. Lek area characteristics of capercaillie (Tetrao urogallus) in eastern Finland as analysed from satellite-based forest inventory data. Scand. J. Forest Res. 20, 358-369.

Miettinen, J., Helle, P., Nikula, A., Niemelä, P., 2008. Large-scale landscape composition and Capercaillie (Tetrao urogallus) density in Finland. Ann. Zool. Fenn. 45, 161-173.

Mikusiński, G., Pressey, R.L., Edenius, L., Kujala, H., Moilanen, A., Niemelä, J., Ranius, T., 2007. Conservation planning in forest landscapes of Fennoscandia and an approach to the challenge of countdown 2010. Conserv. Biol. 21, 1445-1454.

Millennium Ecosystem Assessment, 2005. Ecosystems and Human Wellbeing: Biodiversity Synthesis. World Resources Institute, Washington, DC.

Mönkkönen, M., 1999. Managing Nordic boreal forest landscapes for biodiversity: ecological and economic perspectives. Biodivers. Conserv. 8, 85-99.

Mörtberg, U., Karlström, A., 2005. Predicting forest grouse distribution taking account of spatial autocorrelation. J. Nat. Conserv. 13, 147-159. 
Moss, R., Picozzi, N., Summers, R.W., Baines, D., 2000. Capercaillie Tetrao urogallus in Scotland - demography of a declining population. Ibis 142, 259-267.

Moss, R., Oswald, J., Baines, D., 2001. Climate change and breeding success: decline of the capercaillie in Scotland. J. Anim. Ecol. 70, 47-61.

Mykrä, S., Kurki, S., Nikula, A., 2000. The spacing of mature forest habitat in relation to species-specific scales in managed boreal forests in NE Finland. Ann. Zool. Fenn. 37, 79-91.

Pakkala, T., Pellikka, J., Lindén, H., 2003. Capercaillie Tetrao urogallus - a good candidate for an umbrella species in taiga forests. Wildlife Biol. 9, 309-316.

Park, K.J., Graham, K.E., Calladine, J., Wernham, W., 2008. Impacts of birds of prey on gamebirds in the UK: a review. Ibis 150 (Suppl. 1), 9-26.

Quevedo, M., Bañuelos, M.J., Obeso, J.R., 2006. The decline of Cantabrian capercaillie: how much does habitat configuration matter? Biol. Conserv. 127, 190-200.

Rajala, P., 1974. The structure and reproduction of Finnish populations of capercaillie, Tetrao urogallus, and black grouse, Lyrurus tetrix, on the basis of late summer census data from 1963-66. Finn. Game Res. 35, 1-51.

Ranta, E., Lindström, J., Lindén, H., 1995. Synchrony in tetraonid population dynamics. J. Anim. Ecol. 64, 767-776.

Ranta, E., Kaitala, V., Lindström, J., 1999. Spatially autocorrelated disturbances and patterns in population synchrony. Proc. R. Soc. Lond. B 266, 1851-1856.

Rassi, P., Väisänen, R., 1987. Threatened Animals and Plants in Finland. English Summary of the Report of the Committee for the Conservation of Threatened Animals and Plants in Finland. Ministry of the Environment, Helsinki.

Reinikainen, A., Mäkipää, R., Vanha-Majamaa, I., Hotanen, J.-P. (Eds.), 2000. Changes in the Frequency and Abundance of Forest and Mire Plants in Finland Since 1950. Tammi, Helsinki (in Finnish with English summary).

Rolstad, J., Wegge, P., 1987a. Distribution and size of capercaillie leks in relation to old forest fragmentation. Oecologia 72, 389-394.

Rolstad, J., Wegge, P., 1987b. Habitat characteristics of Capercaillie Tetrao urogallus display grounds in southeastern Norway. Holarctic Ecol. 10, 219-229.

Rolstad, J., Wegge, P., 1989a. Effects of logging on Capercaillie Tetrao urogallus leks. II. Cutting experiments in southeastern Norway. Scand. J. Forest Res, 4, 11-17.

Rolstad, J., Wegge, P., 1989b. Effects of logging on Capercaillie Tetrao urogallus leks. III. Extinction and recolonization on lek populations in relation to clearfelling and fragmentation of old forest. Scand. J. Forest Res. 4, 129-135.

Rolstad, J., Rolstad, E., Wegge, P., 2007. Capercaillie Tetrao urogallus lek formation in young forest. Wildlife Biol. 13 (Suppl. 1), 59-67.

Sachot, S., Perrin, N., Neet, C., 2006. Viability and management of an endangered Capercaillie (Tetrao urogallus) metapopulation in the Jura Mountains, western Switzerland. Biodivers. Conserv. 15, 2017-2032.

Sæther, B.-E., Sutherland, W.J., Engen, S., 2004. Climate influences on avian population dynamics. In: Møller, A., Fiedler, W., Berthold, P. (Eds.), Birds and Climate Change. A dvances in Ecological Research, vol. 35. Elsevier Academic Press, Kidlington, UK, pp. 185-209.

Saniga, M., 2003. Causes of the population decline in Capercaillie (Tetrao urogallus) in the West Carpathians. Biol. Bratisl. 58, 265-273.

Schmiegelow, F.K.A., Mönkkönen, M., 2002. Habitat loss and fragmentation in dynamic landscapes: avian perspectives from the boreal forest. Ecol. Appl. 12, 375-389.

Segelbacher, G., Storch, I., 2002. Capercaillie in the Alps: genetic evidence of metapopulation structure and population decline. Mol. Ecol. 11, 1669-1677.

Segelbacher, G., Höglund, J., Storch, I., 2003. From connectivity to isolation: genetic consequences of population fragmentation in Capercaillie across Europe. Mol. Ecol. 12, 1773-1780.

Sjöberg, K., 1996. Modern forestry and the Capercaillie. In: DeGraaf, R.M., Miller, R.I. (Eds.), Conservation of Faunal Diversity in Forested Landscapes. Chapman \& Hall, London, pp. 111-135.

Storaas, T., Kastdalen, L., Wegge, P., 1999. Detection of forest grouse by mammalian predators: a possible explanation for high brood losses in fragmented landscapes. Wildlife Biol. 5, 187-192.

Storch, I., 1993a. Patterns and strategies of winter habitat selection in alpine Capercaillie. Ecography 16, 351-359.
Storch, I., 1993b. Habitat selection by Capercaillie in summer and autumn: is bilberry important? Oecologia 95, 257-265.

Storch, I., 1997. Male territoriality, female range use, and spatial organisation of Capercaillie Tetrao urogallus leks. Wildlife Biol. 3, 149-161.

Storch, I., 2000. Conservation status and threats to grouse worldwide: an overview. Wildlife Biol. 6, 195-204.

Storch, I., 2007. Conservation status of grouse worldwide: an update. Wildlife Biol. 13 (Suppl. 1), 5-12.

Swenson, J.E., Angelstam, P., 1993. Habitat separation by sympatric forest grouse in Fennoscandia in relation to boreal forest succession. Can. J. Zool. 71, 1303-1310

Tasanen, T., 2006. Review on the forest history of Finland from the late Mediaeval to end of 1800s. In: Rauhalahti, M. (Ed.), Vuosilusto 2004-2005: Essays on the History of Finnish Forestry. Vammalan Kirjapaino, Vammala, pp. 4-32.

The Swedish Bird Survey, 2010. <http://www.zoo.ekol.lu.se/birdmonitoring/resvinterfagel.htm> (9 February, in Swedish).

Thiel, D., Unger, C., Kéry, M., Jenni, L., 2007. Selection of night roosts in winter by Capercaillie Tetrao urogallus in Central Europe. Wildlife Biol. 13 (Suppl. 1), $73-$ 86.

Thomas, C.D., Lennon, J.J., 1999. Birds extend their ranges northwards. Nature 399 213.

Tiihonen, P., 1966. Fourth National Forest Inventory in Finland. 3. Northern wate system areas and forestry board districts. Metsäntutkimuslaitoksen Julkaisuja 60, 1-67 (in Finnish with English summary).

Tiihonen, P., 1968. Fourth National Forest Inventory in Finland. 4. Forest resources in Finland in 1960-63. Metsäntutkimuslaitoksen Julkaisuja 66, 1-30 (in Finnish with English summary)

Tomppo, E., Katila, M., Moilanen, J., Mäkelä, H., Peräsaari, J., 1998. Kunnittaiset metsävaratiedot 1990-94. Metsätieteen Aikakauskirja 4B/1998, 619-839 (in Finnish).

Valkeajärvi, P., Ijäs, L., 1986. On the display requirements of Capercaillie in Central Finland. Suomen Riista 33, 5-18 (in Finnish with English summary).

Virkkala, R., 1991. Population trends of forest birds in a Finnish Lapland landscape of large habitat blocks: consequences of stochastic environmental variation or regional habitat alteration? Biol. Conserv. 56, 223-240.

Wallgren, M., Bergström, R., Danell, K., Skarpe, C., 2009. Wildlife community patterns in relation to landscape structure and environmental gradients in Swedish boreal ecosystem. Wildlife Biol. 15, 310-318.

Wegge, P., Rolstad, J., 1986. Size and spacing of Capercaillie leks in relation to socia behavior and habitat. Behav. Ecol. Sociobiol. 19, 401-408.

Wegge, P., Olstad, T., Gregersen, H., Hjeljord, O., Sivkov, A.V., 2005. Capercaillie broods in pristine boreal forest in northwestern Russia: the importance of insects and cover in habitat selection. Can. J. Zool. 83, 1547-1555.

\section{Glossary}

Autoregressive models: A type of time series models that use previous observations to predict the values of focal observations. In population dynamics, these models are typically used to model (potentially delayed) density dependent regulation.

Lekking site, lek: A site where Capercaillie males collect to display and copulate with females in spring. A single lek covers approximately 300 hectares of forest including the daily territories of the males, i.e. the area for the lekking males to rest and feed between the actual displaying and mating.

Lekking population: Local Capercaillie population, mainly the adult males and females attending the same lekking sites and using same seasonal home ranges and nesting sites year after year (see e.g. Storch, 1997).

Process error: Source of error (random noise) stemming from uncontrolled factors, in population dynamics typically demographic and environmental stochasticity. Often used to describe random variation that is not due to measurement error.

Vector autoregressive models: Multivariate generalizations of autoregressive models 